\title{
EFEKTIVITAS PEMBELAJARAN ONLINE DI POLITEKNIK KRIDATAMA PADA ERA COVID-19
}

\author{
Neneng Siti Maryam \\ Universitas Mandiri \\ nenengsm70@gmail.com
}

\begin{abstract}
Early March 2020, the corona virus began to spread in Indonesia. To suppress the wider spread of the virus, the government made policies regarding social restrictions. This has resulted in many schools and colleges, offices and companies, and other public places, deciding whether employees or their students should work or study from home. This study aims to examine the effectiveness of online learning during the Corona virus pandemic in Bandung Kridatama Polytechnic students. The research method used is descriptive qualitative method, and data collection techniques are carried out through observation, interviews and documentation. While the analysis of data acquisition was carried out by collecting data, reducing data, and drawing conclusions. The results of the study revealed that online learning carried out during the Corona virus pandemic was ineffective because obstacles were still found that interfered with the learning process, including the absence of two-way communication between students and lecturers, Besides other obstacles, namely students who do not have enough quotas to take part in online learning, or lecturers who do not understand technology so that learning is not carried out using online learning applications but through Whatsapp groups.
\end{abstract}

Keywords: learning, online learning, pandemic, Corona virus

\begin{abstract}
Abstrak - Awal bulan Maret tahun 2020, virus corona mulai menyebar di Indonesia. Untuk menekan penyebaran virus yang lebih luas lagi, pemerintah membuat kebijakan mengenai pembatasan sosial. Hal tersebut mengakibatkan banyak sekolah dan kampus, kantor dan perusahaan, serta tempat-tempat publik lainnya, memutuskan para karyawan atau anak didiknya untuk bekerja atau belajar dari rumah. Penelitian ini bertujuan untuk mengkaji efektivitas pembelajaran online di masa pandemi virus Corona pada mahasiswa Politeknik Kridatama Bandung. Metode penelitian yang digunakan adalah metode deskriptif kualitatif, dan teknik pengumpulan data dilakukan melalui observasi, wawancara dan dokumentasi. Sedangkan analisis perolehan data dilakukan dengan pengumpulan data, reduksi data, dan penarikan kesimpulan. Hasil dari penelitian mengungkapkan bahwa pembelajaran online yang dilaksanakan selama masa pandemi virus Corona kurang efektif karena masih ditemukan hambatan yang mengganggu proses pembelajaran diantara-Nya tidak terjalinnya komunikasi dua arah antara mahasiswa dan dosen, disamping hambatan-hambatan lainnya yaitu mahasiswa yang tidak memiliki cukup kuota untuk mengikuti pembelajaran online, atau dosen yang kurang memahami teknologi sehingga pembelajaran tidak dilakukan dengan menggunakan aplikasi pembelajaran online tetapi melalui grup Whatsapp.
\end{abstract}

Kata Kunci: pembelajaran, pembelajaran online, pandemik, virus Corona

\section{PENDAHULUAN}

Virus Corona masuk ke Indonesia untuk pertama kalinya pada awal bulan Maret tahun 2020, ditandai dengan adanya warga yang positif terinfeksi.

Ternyata kehadiran wabah ini mengakibatkan dampak perubahan di segala bidang, salah satu diantara-Nya perubahan pada lembaga pendidikan dengan mengalihkan proses pembelajaran tatap muka pada pembelajaran online (Syahmina, Ifrah, et.al., 2020).

Salah satu upaya pemerintah untuk menekan penyebaran virus Corona adalah memberlakukan pembelajaran online bagi peserta didik mulai dari tingkat dasar sampai perguruan tinggi. Agar pembelajaran online dapat terlaksana dan memenuhi standar pendidikan, maka digunakan Teknologi dan Komunikasi (M, Mutiani dan M, Faisal, 2019). 
Kebijakan pemerintah yang diterbitkan secara mendadak tersebut mengakibatkan pihak-pihak yang berhubungan dengan sektor pendidikan harus segera membuat penyesuaian dalam proses pembelajaran online karena pembelajaran online membutuhkan lebih banyak energi dan kreativitas dibandingkan dengan pembelajaran tatap muka.

Agar tetap bisa mengajar mahasiswa, para tenaga pendidik harus melakukan perubahan dengan melakukan pembelajaran secara online dan dilakukan dari rumah (Argaheni, 2020). Pembelajaran yang diberikan kepada mahasiswa melalui internet merupakan salah satu bentuk usaha dari pembelajaran online (Yolandasari, 2020).

Banyak aplikasi pembelajaran online yang dapat digunakan untuk mendukung proses belajar mengajar di kampus misalnya Whatsapp, Zoom, Googleclassroom, dan lain-lain. Kondisi peserta didik dan tenaga pendidik yang bertemu secara online dalam proses pembelajaran dimaksudkan untuk menjaga jarak fisik dan sosial (Kurniasari, Asrilia, et.al., 2020).

Tetapi ternyata perkuliahan yang dilakukan secara online membuat mahasiswa cepat merasa jenuh. Pembelajaran yang dilakukan masih menitikberatkan pada kemampuan intelektual mahasiswa dan terpusat pada dosen sehingga kurang menggali potensi yang dimiliki mahasiswa.(Yuki, 2019). Permasalahan tersebut perlu diatasi dengan melakukan pembenahan bagi tenaga pendidik maupun peserta didik agar peserta didik dapat berperan serta aktif baik fisik, emosional, maupun intelektual (Juwayni, Muhamad dan Marwah, 2020).

Pembelajaran yang bermutu adalah pembelajaran dimana terjadi interaksi maksimal antara peserta didik dengan tenaga pendidik beserta bahan ajar dalam suasana pembelajaran. Hal ini dimaksudkan agar mahasiswa dapat mencapai tujuan pembelajaran secara optimal. Ujung dari keseluruhan susunan pembelajaran yang dilaksanakan merupakan tujuan dari pembelajaran (Kurniasari, Asrilia, et.al., 2020).

Efektivitas pembelajaran pun perlu dipertimbangkan untuk mengetahui capaian tujuan yang telah ditetapkan sebelumnya (Suartini, 2020). Salah satu indikator yang menunjukkan bahwa proses pembelajaran dikatakan efektif apabila tujuan pembelajaran tercapai secara maksimal dan mahasiswa dapat menyerap materi yang diberikan. Oleh karena itu, dibutuhkan pula partisipasi aktif mahasiswa dalam pembelajaran online agar pembelajaran online dapat berjalan efektif.

Banyak penelitian yang dilakukan peneliti sebelumnya mengenai keefektifan pembelajaran online dalam masa pandemi virus Corona, diantaraNya yang mengatakan bahwa pembelajaran daring efektif untuk mahasiswa yang tinggal di wilayah dengan koneksi internet yang baik serta sarana dan prasarana yang mendukung (Fitriani, Aas Aliana. et.al., 2020), ada pula yang mengatakan bahwa pelaksanaan pembelajaran dari rumah cukup efektif dengan syarat guru mampu merancang pembelajaran yang mudah dipahami dan menarik (Kurniasari, Asrilia, et.al., 2020).

Peneliti lain mengatakan bahwa pembelajaran daring belum efektif karena peserta didik dan tenaga pendidik belum siap dalam memanfaatkan teknologi (Damayanti, 2020), sementara peneliti lainnya mengungkapkan bahwa kurang efektifnya perkuliahan secara online disebabkan kurangnya edukasi mahasiswa dalam teknologi dan minimnya sarana dan prasarana (Hamidi, 2020). 
Ada pula peneliti yang mengatakan bahwa pembelajaran daring kurang efektif disebabkan kurangnya dukungan peralatan, anggaran tinggi, pengaturan waktu, dan jaringan yang kurang baik (Feri, Lukman dan Andi Sahtiani Sahrir, 2020), sementara hasil penelitian lain mengungkapkan bahwa pembelajaran daring berjalan efektif dengan menggunakan media pembelajaran yang menarik (Mustakim, 2020), dan peneliti lain mengatakan bahwa pembelajaran jarak jauh cukup efektif meskipun ditemukan masalah dalam interaksi sosial guru dan siswa (Abidin, Zainal, et.al., 2020).

Dari penelitian-penelitian tersebut, masih jarang peneliti yang melakukan penelitian tentang efektivitas pembelajaran online dihubungkan dengan partisipasi mahasiswa. Oleh karena itu, penelitian ini perlu dilakukan guna mengetahui efektivitas dalam pembelajaran online di masa pandemi virus Corona apabila kurang didukung oleh partisipasi mahasiswa. Apakah pembelajaran online tersebut efektif dilakukan atau justru sebaliknya, menjadi tidak efektif karena hanya dosen yang aktif dalam pembelajaran daring tersebut.

Diharapkan penelitian ini dapat bermanfaat sebagai informasi tambahan dalam hal pembelajaran online bagi civitas akademika di Politeknik Kridatama Bandung.

\section{METODE PENELITIAN}

Penelitian yang dilakukan menggunakan metode kualitatif dimana data yang disajikan merupakan hasil wawancara mendalam, observasi langsung, dan kajian dokumen. Teknik pengumpulan data dengan melalui wawancara pada responden.

Penelitian dilakukan pada Program Studi Administrasi Bisnis di semester ganjil tahun ajaran 2020/2021. Adapun yang menjadi responden adalah 5 orang dosen program studi dan 15 orang mahasiswa yang terdiri dari 9 orang mahasiswa semester 1, 2 orang mahasiswa semester 3 , dan 4 orang mahasiswa semester 5 . Selain wawancara, dilakukan juga dokumentasi dan studi literatur melalui buku, jurnal-jurnal penelitian sebelumnya, dan observasi dengan mengamati sarana dan prasarana, pendidik dan tenaga kependidikan.

Adapun analisis data yang dilakukan menggunakan model (Miles, Mathew B. \& A. Michael Hubberman, 1992) yaitu reduksi data untuk memilih informasi yang diperlukan dari catatan tertulis di lapangan, penyajian data menampilkan susunan informasi yang kemungkinan dapat dijadikan sebagai kesimpulan dan tindakan yang diambil, dan langkah terakhir yaitu penarikan kesimpulan dan verifikasi.

\section{HASIL DAN PEMBAHASAN}

Berdasarkan hasil wawancara terhadap responden maka didapatkan informasi bahwa pembelajaran online-ini sebagai pengganti pembelajaran tatap muka yang tidak bisa dilaksanakan karena kondisi pandemi, sehingga dosen dan mahasiswa harus memanfaatkan pembelajaran online sebagai media belajar agar hak dan kewajiban sebagai civitas akademika tetap dapat dipenuhi.

Pembelajaran online yang dilaksanakan di Politeknik Kridatama menggunakan aplikasi yang disesuaikan dengan kebutuhan agar pembelajaran online berjalan efektif. Tetapi dalam pelaksanaannya terdapat masalah diantara-Nya dalam hal: (1) Kesiapan dosen dalam mengajar; (2) Ketersediaan hardware dan software untuk mendukung efektivitas pembelajaran online; (3) Ketersediaan akses dan koneksi internet yang merupakan kunci pembelajaran online, karena tidak jarang hal ini menjadi penghambat dalam 
pembelajaran ketika sulit mendapatkan akses internet karena keterbatasan kuota serta koneksi internet yang tidak stabil. Belajar daring menjadi salah satu isu yang berdampingan dengan kasus pandemi Covid-19. Hal ini disebabkan metode belajar online yang disebut sebagai pendidikan jarak jauh (PJJ) membawa berbagai pro-kontra di masyarakat (Hanum, Fauziah dan Heylen Amildha Y., 2020).

Pelaksanaan pembelajaran online yang dilakukan di Politeknik Kridatama dengan melalui platform Google Classroom, Whatsapp group atau aplikasi Zoom, masih kurang efektif karena kurangnya dukungan partisipasi mahasiswa dalam merespons pembelajaran. Mereka jarang hadir dalam tatap muka online atau sering terlambat masuk kelas sehingga hal ini menghambat tercapainya tujuan pembelajaran karena dosen tidak mengetahui apakah mahasiswa bisa mengikuti dan paham dengan materi yang disampaikan atau tidak.

Untuk mengetahui efektivitas pembelajaran online berdasarkan pengalaman mahasiswa, dilakukan wawancara terhadap dosen dan mahasiswa yang terlibat sebagai partisipan penelitian. Hasilnya 15 dari 20 responden merasakan pembelajaran online belum efektif karena akses bertanya tidak seluas dan sebebas seperti saat pembelajaran tatap muka langsung ketika berada di kelas, dan materi pembelajaran tidak dijelaskan secara detail. Adapun alasan dari sisi dosen adalah disebabkan mahasiswa jarang hadir di kelas online, atau mahasiswa sering terlambat masuk ke kelas online sehingga sulit bagi dosen untuk mengelola waktu pembelajaran daring yang akhirnya materi tidak bisa disampaikan secara maksimal.

Berdasarkan wawancara yang dilakukan terhadap responden maka dapat diketahui bahwa kendala ini disebabkan mahasiswa tidak memiliki kuota yang cukup untuk bisa mengikuti kelas pembelajaran daring, atau koneksi internet yang kurang baik sehingga membuat mahasiswa kurang bersemangat untuk mengikuti pembelajaran daring.

Selain itu, karena mayoritas mahasiswa Politeknik Kridatama sudah bekerja maka pembelajaran daring yang dilaksanakan di rumah masing-masing dengan jam kuliah mulai pukul 17:00 WIB, membuat mahasiswa tersebut tidak bisa konsentrasi dan fokus pada pembelajaran karena pada jam tersebut mereka baru tiba dari tempat kerja sehingga masih dengan perasaan lelah mereka harus mengikuti pembelajaran daring yang membuat mereka jenuh dengan kondisi pembelajaran yang monoton karena dilakukan sendirian di rumah, berbeda ketika mereka melakukan pembelajaran tatap muka di kampus, di mana mereka bisa bersenda gurau dengan mahasiswa lain sehingga bisa menyegarkan suasana.

Kendala lain adalah bagi mahasiswa yang sudah berkeluarga, ketika mereka melakukan pembelajaran online di rumah, mereka tidak bisa fokus karena tidak jarang mereka diganggu oleh putra-putrinya yang ingin ditemani atau ingin bermain dengan ibu atau ayahnya. Pada dasarnya dosen sudah melakukan persiapan pembelajaran online sebaik mungkin yaitu dengan membuat rencana pembelajaran yang sederhana, kreatif dan tidak membosankan, agar mahasiswa dapat mengikuti pembelajaran dengan senang hati tanpa merasa terbebani. Tetapi hal itu akan menjadi sia-sia apabila tidak diikuti dengan partisipasi aktif mahasiswa karena pembelajaran menjadi tidak efektif sehingga tujuan pembelajaran yang diharapkan tidak tercapai karena dosen tidak dapat mengetahui dan 
mengukur kemampuan pemahaman mahasiswa terhadap materi yang diberikan.

Untuk mengatasi permasalahan tersebut, dosen memberikan motivasi kepada mahasiswa dengan cara memberikan nasihat-nasihat yang bisa membangkitkan semangat belajar mahasiswa pada saat sebelum pembelajaran online dimulai, atau memberikan reward berupa tambahan nilai apabila mahasiswa selalu hadir tepat waktu dan aktif dalam pembelajaran daring.

Selain itu, dosen berusaha menggunakan media pembelajaran yang menarik agar mahasiswa termotivasi untuk selalu hadir dalam pembelajaran online yaitu dengan cara menyajikan materi dalam bentuk Youtube, Power Point, diskusi, atau presentasi. Oleh karena itu, kegiatan penilaian yang diberikan dosen tidak hanya mengutamakan nilai berdasarkan kehadiran dan kedisiplinan mahasiswa dalam mengumpulkan tugas, tetapi juga berdasarkan keaktifan mahasiswa dalam bertanya, menanggapi pertanyaan, dan memberikan analisis terhadap studi kasus yang diberikan selama pembelajaran daring berlangsung.

Kurangnya komunikasi dua arah secara efektif antara dosen dengan mahasiswa serta antar mahasiswa, menyebabkan proses pembelajaran online dari rumah ini lama kelamaan menjadi membosankan, sehingga dosen dituntut untuk memberikan pembelajaran secara ringkas dan sederhana, lebih variatif dalam memberikan soal, serta pemberian tugas sebaiknya disertai dengan instruksi yang jelas agar dapat dipahami dengan mudah oleh mahasiswa sehingga tidak menimbulkan multitafsir.

Adapun kelebihan pembelajaran daring berdasarkan wawancara dengan responden adalah: (1) Mahasiswa merasa lebih rileks dan tidak tegang karena mereka hanya bertatapan dengan layar komputer; (2) Mahasiswa memiliki lebih banyak waktu di rumah karena mereka tidak harus ke kampus yang kemungkinan jaraknya cukup jauh dari tempat tinggal sehingga hal ini cukup melelahkan dan memakan banyak waktu; (3) Mengurangi ketergantungan mahasiswa pada dosen karena dengan pembelajaran online, mereka tidak hanya bisa bertanya pada dosen, tetapi juga bisa bertanya pada orang rumah atau berselancar di internet sehingga hal ini semakin menambah wawasan mahasiswa; (4) Tidak perlu terburu-buru berangkat ke kampus pagi-pagi.

Sedangkan kekurangan dari pembelajaran online berdasarkan wawancara dengan responden adalah: (1) Mahasiswa merasa kurangnya sosialisasi dengan mahasiswa lain karena keterbatasan ruang dan komunikasi; (2) Mahasiswa yang tinggal di daerah kesulitan dalam koneksi internet yang tidak stabil; (3) Dosen dan mahasiswa tidak dapat berinteraksi secara langsung seperti halnya pada saat kuliah tatap muka, sehingga dosen tidak dapat mengetahui perkembangan pemahaman mahasiswa terhadap materi yang diberikan karena dalam prosesnya sering kali mahasiswa terlambat masuk dalam kelas online sehingga mahasiswa merasa waktu pembelajaran menjadi lebih sedikit.

Terkait dengan suasana pembelajaran online yang dilaksanakan selama ini, sebanyak 12 responden mengatakan bahwa pembelajaran online dirasakan kurang menyenangkan karena terkendala dengan adanya gangguan koneksi internet pada saat pembelajaran berlangsung sehingga menghambat dalam penyampaian dan pemahaman materi, sementara 8 responden mengatakan bahwa pembelajaran online cukup menyenangkan karena dapat dilakukan dari rumah dan hal itu cukup menghemat waktu apabila dibandingkan 
harus berangkat ke kampus untuk kuliah tatap muka.

Berdasarkan pada permasalahan yang telah diungkapkan sebelumnya, agar pembelajaran online berlangsung efektif dengan adanya partisipasi aktif mahasiswa dalam kehadiran di kelas, maka perlu dilakukan perbaikanperbaikan diantara-Nya:

Meningkatkan kreativitas dosen dengan menciptakan suasana belajar yang menyenangkan misalnya menggunakan mind map atau Power Point; (2) Melaksanakan pembelajaran offline sebulan sekali untuk mengevaluasi pemahaman mahasiswa terhadap materi yang diberikan, terutama terkait dengan mata kuliah praktik, agar dosen mengetahui perkembangan mahasiswa selama pembelajaran online.

\section{SIMPULAN DAN SARAN}

Pembelajaran online yang dilaksanakan di Politeknik Kridatama Bandung belum efektif karena rendahnya tingkat partisipasi mahasiswa dalam mengikuti kelas online. Pembelajaran online seperti sebuah keterpaksaan yang harus dilakukan karena mahasiswa dituntut hadir di kelas online sebagai salah satu bentuk partisipasi aktif mahasiswa. Adanya kendala yang dihadapi mahasiswa tidak jarang menurunkan semangat mahasiswa untuk hadir dalam kelas dimana kendala tersebut diantaraNya koneksi internet yang kurang bagus, kuota yang terbatas, kelelahan karena baru pulang kerja tetapi sudah harus bergabung dalam kelas online, dan gangguan dari anak bagi yang sudah berkeluarga karena pembelajaran dilakukan di rumah. Selain itu, sebagian besar responden tidak memiliki komputer sehingga proses belajarmengajar menjadi terhambat.

Selain itu, dalam pelaksanaannya masih ada dosen yang hanya memberikan tugas saja sehingga dosen tidak mengetahui apakah mahasiswanya paham atau tidak dengan materi yang diberikan. Hal ini membuat mahasiswa malas untuk mengikuti pembelajaran online karena membuat mereka bosan dan stres dengan tugas-tugas yang diberikan.

Rekomendasi untuk mengatasi kendala yang dihadapi selama pembelajaran online adalah dengan memberikan motivasi terhadap mahasiswa agar bisa hadir dalam pembelajaran online dengan memberikan reward berupa tambahan nilai atau dengan memberikan hadiahhadiah sederhana seperti uang, pulsa/kuota, cokelat, alat tulis dan hadiah sederhana lainnya yang bisa dikirimkan ke mahasiswa melalui aplikasi pengiriman.

Selain itu, diharapkan dosen dapat melaksanakan pembelajaran online dengan memanfaatkan media sosial yang ada untuk menarik minat dan antusias peserta didik. Adapun media pembelajaran yang direkomendasikan adalah dengan melalui Instagram (IG) live sehingga mahasiswa bisa dengan aktif melakukan tanya jawab atau dengan melalui aplikasi tiktok untuk menyampaikan materi yang sederhana.

Diharapkan peneliti selanjutnya melakukan penelitian dengan lebih memfokuskan pada motivasi belajar mahasiswa dan hendaknya dapat mengembangkan penelitian ini dengan mencari faktor lain yang mempengaruhi kemauan belajar mahasiswa yang dalam penelitian ini belum dapat dilakukan karena keterbatasan waktu, sehingga hasil penelitian dapat mengungkapkan manfaat lain dari pembelajaran online.

\section{DAFTAR PUSTAKA}

Aas Aliana Fitriani H, Robiah Al Adawiyah, Prima Ayu R.M. (2020). Efektivitas Pembelajaran online di Masa Pandemi Covid19. Jurnal Sosial, Vol. 21 No. 2. 
Ali Sadikin, Afreni Hamidah. (2020). Pembelajaran Daring di Tengah Pandemi. Biodik.

Argaheni, N. B. (2020). Sistematik Review, Dampak Perkuliahan Daring Saat Pandemi Covid-19 Terhadap Mahasiswa Indonesia. Placentum, Vol. 8 (2), 100-110.

Asrilia Kurniasari, Fitroh Setyo Putro Pribowo, Deni Adi Putra. (2020). Analisis Efektivitas Pelaksanaan Belajar dari Rumah (BDR) selama Pandem Covid-19. Jurnal Review Pendidikan Dasar, Vol. 6 No. 3, 1-8.

Damayanti, A. (2020). Efektivitas Pembelajaran Daring di Masa Pandemi Covid-19 pada Perguruan Tinggi Keagamaan Katolik. Edutech, Vol. 19 No.3.

Ditjen Dikti Kemdikbud. (2012, February 2). Surat Dirjen Dikti No. 152/E/T/2012 : Wajib Publikasi Ilmiah Bagi S1/S2/S3. Retrieved from Kementrian Riset, Teknologi dan Pendidikan Tinggi Kopertis WIlayah XII Maluku Utara: http://www.kopertis12.or.id/201 2/02/01/surat-dirjen-dikti-no152et2012-tentang-wajibpublikasi-ilmiah-bagis1s2s3.html

Fauziah Hanum, Heylen Amildha Yanuarita. (2020). Efektivitas Pembelajaran dalam Jaringan (daring) Selama Masa Pandemi Covid-19 di Kabupaten Jombang. Jurnal Ilmu Sosial dan Pendidikan, Vol. 4 No. 4 .

Hamidi, A. (2020). Workshop Efektivitas Pembelajaran Daring pada Masa Pandemi Covid-19 di Prodi Ikor. Jurnal Maenpo, Vol. 10 No. 2, 109-119.
Ifrah Syahmina, Indayana Febriani Tanjung, Rohani. (2020). Efektivitas Pembelajaran Biologi Pada Masa Pandemi Covid-19 di Madrasah Negeri Medan. Biolokus, Volume 3, Nomor 2, 321-332.

Janah, W. A., Abbas, E.W., Mutiani. (2020). The Contribution of Leadership Value of Nadjmi Adhani as a Learning Resources on Social Studies. The Innovation of Social Studies , 1 (2), 188-196.

Lukman Feri, Andi Sahtiani Sahrir. (2020). Efektivitas Pembelajaran Daring di Tengah Pandemi Covid-19. Panrita, Vol. 1 No. 1.

Mastiah. (2020). Efektivitas Pembelajaran Daring di Masa Pandemi Menuju Era New Normal. Universitas Lambung Mangkurat.

Miles, Mathew B. \& A. Michael Hubberman. (1992). Analisa Data Kualitatif, diterjemahkan oleh Tjetjep Rohendi Rodidi. Jakarta: UI Press.

Muhamad Juwayni, Marwah. (2020). Peningkatan Motivasi dan Hasil Belajar Analisis Hikayat Melalui Media Pembelajaran Kooperatif Tipe NHT pada Kelas SMA Daar El Mu'min Kampung Kaduengang Kecamatan Losari Kabupaten Pandeglang. Jurnal Soshum Insentif, Volume 3, No.1.

Mustakim. (2020). Efektivitas Pembelajaran Daring Menggunakan Media Online selama Pandemi Covid-19 pada Mata Pelajaran Matematika. Al Asma: Jurnal of Islamic Education, Vol. 2 No. 1, 1-12. 
Mustakim. (2020). Efektivitas Pembelajaran Daring Menggunakan Media Online Selama Pandemi Covid-19 pada Mata Pelajaran Matematika. Uin Alaudin.

Mutiani M., Faisal M. (2019). Urgency of the 21st Century Skills and Social Capital in Social Studies. The Inovation of Social Studies, 1 (1), 1-11.

Peraturan Kementrian Pendidikan dan Kebudayaan, R. I. (Nomor 109/2013). Penyelenggaraan Pendidikan Jarak Jauh pada Perguruan Tinggi. Jakarta.

Peraturan Kementrian Pendidikan dan Kebudayaan, R. I. (Nomor 36962/MPM.A/HK/2020).

Pembelajaran Secara Daring dan Bekerja dari Rumah dalam Rangka Pencegahan Penyebaran Corona Virus Disease (Covid19). Jakarta.

Suartini, N. K. (2020). Perspektif Mahasiswa dan Dosen terhadap Efektivitas Pembelajaran Daring Selama Pandemi Covid-19. Cetta, Vol. 3 No. 3, 521-534.

Subiyakto B., Mutiani, M. . (2019). Internalisasi Nilai Pendidikan Melalui Aktivitas Masyarakat Sebagai Sumber Belajar Ilmu Pengetahuan Sosial. Khazanah, 17 (1), 137-166.

Wahyuningsih, S., Abbas, E.W., Mutiani. (2020). Implementation of Leadership value of Rudy Resnawan as a Learning Resources on Social Studies. The Innovation of Social Studies, 1 (2), 169-177.

Yolandasari, M. B. (2020). Efektivitas Pembelajaran Daring dalam
Pembelajaran Bahasa Indonesia di Kelas II A MI Unggulan Miftahul Huda Tumang Cepogo Boyolali Tahun Pelajaran 2019/2020. Salatiga: Institut Agama Islam Negeri.

Yuki, L. K. (2019). Pembelajaran Membaca Puisi dengan Model COntextual Teaching and Learning (CTL). Jurnal Soshum Insentif, Volume 2, No.2.

Zainal Abidin, Adang Hudaya, Dinda Anjani. (2020). Efektivitas Pembelajaran Jarak Jauh pada Masa Pandemi Covid-19. Research and Development Journal of Education (Special Edition), 131-146. 